\title{
Evaluation of the effect of the salinity of irrigation water on the yield of castor plant hybrids (Ricinus communis L.) in Mexico
}

\begin{abstract}
The study consists of evaluating the response of three hybrids of castor plant (Ricinus communis L.), Zoya 856, Olga 864 and Galit K-93, to four irrigation treatments at different salt concentrations $\left(2.3,3.12,3.9\right.$ and $\left.4.68 \mathrm{dS} \mathrm{m}^{-1}\right)$ simultaneously. The objective was to compare the yield between hybrids for each treatment, as well as to determine the effects caused by excess salt in the stages of germination, flowering and growth of the plant. The research was conducted in Block 1916 of the Yaqui Valley, located in the state of Sonora, Mexico. Irrigation water was obtained from a brackish well with $3,900 \mathrm{mg} \mathrm{L}^{-1}$ of total dissolved solids adjacent to the study area and subjected to a desalination process by reverse osmosis using a system with an output of $150 \mathrm{~m}^{3} \mathrm{~d}^{-1}$, equipped with 12 membrane modules (model SWC4-MAX) with dimensions of $0.20 \mathrm{mx} 1.01 \mathrm{~m}$. The results showed that the germination and flowering stages were delayed as the concentration of salts increased. In conclusion, the yield of the hybrids increased under irrigation with higher salinity, with the Olga 864 hybrid having the highest production (2.28 ton $\mathrm{Ha}^{-1}$ with irrigation of $\left.4.68 \mathrm{dS} \mathrm{m}^{-1}\right)$.
\end{abstract}

Keywords: castor plant, desalination, reverse osmosis, yield
Volume 2 Issue 5 - 2018

\author{
Devora-Isiordia Ge,' Valdez-Torres Lc,' \\ Granillo-Moreno Ka, ${ }^{2}$ Robles-Lizarraga A, ${ }^{2}$ \\ Martinez-Macias Mr,' Álvarez-Sánchez J' \\ 'Department of Water Sciences and Environment, Mexico \\ ${ }^{2}$ Master of Science Program in Natural Resources, Technological \\ Institute of Sonora, Mexico
}

Correspondence: Devora-Isiordia Ge, Department of Water Sciences and Environment, Mexico, Email adri_356@hotmail.com

Received: September II, 2018| Published: October 22, 2018

\section{Introduction}

In Mexico, water scarcity has increased in recent years due to factors such as overexploitation of aquifers, high levels of water pollution, population growth and inadequate distribution of water resources, mainly in the northern areas of the country. ${ }^{1}$ In Sonora, located in northwestern Mexico, approximately $95 \%$ of the region is considered arid or semiarid and is characterized by high temperatures and lack of rainfall; Sonora is considered the driest region of the country. ${ }^{2}$ However, this region is one of the dominant places for irrigated crops in Mexico. ${ }^{3}$ The main problems caused by lack of water for agriculture in Sonora are associated with high concentrations of salinity in wells, ranging from 2,000 to $10,000 \mathrm{mg} \mathrm{L}^{-1}$ of total dissolved solids (TDS). These values are caused by overexploitation of aquifers causing problems of saline intrusion. ${ }^{4}$ When this water is supplied in agriculture, the growth and yield of crops are strongly affected by the salinization of soils and by the increase of the osmotic potential in the irrigation water, which leads the plants to become dehydrated as they consume high levels of water salts. ${ }^{5}$ Given these critical scenarios, it is necessary to look for alternatives that allow water to be available for agriculture and for genetic materials that allow acceptable production levels in this type of soil. An alternative is the desalination of water from brackish wells to irrigate crops tolerant of salinity in the soil or of high concentrations of salts in the water without presenting adverse effects, such as reduction of growth, lowered production and foliar damage. ${ }^{6}$ Desalination by reverse osmosis (RO) of seawater or brackish water is the most widely used desalination process for obtaining quality water for human, industrial and agricultural consumption due to its lower consumption of energy and space. . $^{7}$

The castor plant (Ricinus communis L.) is tolerant of salinity and is one of the largest crops not destined for consumption used in arid and semiarid zones. ${ }^{9}$ In addition, the castor plant continues to be of great interest due to the agronomic and technological advantages that have been reported by various investigations carried out in the country, including of its high yield potential in relation to low water requirements, its adaptation to arid and marginal regions of the tropical and subtropical zones, and the fact that it does not compete with human food..$^{10}$ The growth and development of castor plants are affected by high concentrations of salinity in both irrigation water and soil. The limit that has been reported for emergence and growth is $7.1 \mathrm{dS} \mathrm{m}^{-1}$, with which emergence is delayed by 9 days. ${ }^{11}$ Currently, in southern Sonora, Mexico, a castor oil production plant has been installed, which will have international impact with shortterm objectives such as validating the technology used for production and identifying the castor plant's phenological and medium-term behavior. It is hoped that the castor plant can be established in the region as a crop diversification tool due to its high profitability. The objective of this work is to evaluate the yield of three castor plant hybrids at different salinity concentrations in the irrigation water by means of a desalination plant that regulates this parameter to establish the salinity-yield relationship in the crop.

\section{Materials and methods}

\section{Agronomic}

The experiment was conducted in the period February-June 2016 in Block 1916 of the Yaqui Valley, Sonora, located in the northwest of Mexico, at the geographic coordinates $27^{\circ} 11^{\prime} 22.68^{\prime \prime}$ north latitude and $109^{\circ} 53^{\prime} 30.73^{\prime}$ ' west longitude. During the winter season in the Yaqui Valley, which has a predominantly clay soil, approximately 225,000 ha are planted with crops, (Rodríguez et al., 2010). Three castor plant hybrids were evaluated: Zoya 856, Olga 864 and Galit K-93. Four levels of salinity of irrigation water were used. The planting was carried out on February 12 in rows that were $124 \mathrm{~m}$ long by $0.76 \mathrm{~m}$ wide with a separation between plants of $0.3 \mathrm{~m}$. Fertilization was carried out before sowing using $57 \mathrm{~N}-52 \mathrm{P} \mathrm{kg} \mathrm{ha}^{-1}$. The crops were irrigated using a drip system with an output per dropper of $1 \mathrm{~L}$ $\mathrm{h}^{-1}$. Moisture in the soil was controlled with granular matrix sensors (Watermark, considering an appropriate range of 20 to $40 \mathrm{k} \mathrm{Pa}^{-1}$ ). 


\section{Desalination}

From February 12 to June 18, 2016, a desalination plant was operated with a reverse osmosis system with a production flow of 150 $\mathrm{m}^{3} \mathrm{~d}^{-1}$, equipped with 12 modules of Hydranautics brand membranes, model SWC4-MAX, with high rejection. The system had dimensions of $0.20 \mathrm{~m} \mathrm{x} 1.01 \mathrm{~m}$ and $40.87 \mathrm{~m}^{2}$ of effective filtration area, with a maximum working pressure of $800 \mathrm{psi}$, a spacing between membrane modules of $28 \mathrm{~mm}$, a nominal production of $0.315 \mathrm{~L} \mathrm{~s}^{-1}$ and a removal percentage of salts of $99.80 \%$. The permeated water was supplied to the irrigation system at four different salinity concentrations: 2.3 (control), 3.12, 3.90 and $4.68 \mathrm{dS} \mathrm{m}^{-1}$. The parameters of electrical conductivity $\left(\mathrm{dS} \mathrm{m}^{-1}\right)$, TDS $\left(\mathrm{mg} \mathrm{L}^{-1}\right), \mathrm{pH}$ of the permeated water and temperature $\left({ }^{\circ} \mathrm{C}\right)$ were recorded. The product of the desalination plant and well water were mixed to obtain the concentrations of irrigation water treatments used for the castor plant crop. To calculate the mixtures for the water treatments, the following formula was used:

$$
C_{1} \bullet V_{1}+C_{2} \bullet V_{2}=C_{3} \bullet V_{3}
$$

Where $C_{l}$ is the quality of the well water in $\mathrm{mg} \mathrm{L}^{-1}$ of TDS, $V_{l}$ is the volume of well water in liters, $C_{2}$ is the quality of the permeated water (from the desalination plant) in $\mathrm{mg} \mathrm{L}^{-1}$ of TDS, $V_{2}$ is the volume of the permeated water (desalination plant) in liters, $C_{3}$ is the water quality in the treatment in $\mathrm{mg} \mathrm{L}^{-1}$ of TDS, and $V_{3}$ is the volume of the water in the treatment in liters.

\section{Water quality}

In this study, a YSI 556 multiparameter measuring system was used to monitor the field parameters of the water coming from the brackish well, the rejected water, the permeated water produced by the desalination process and the water mixtures prepared with different salinity concentrations. The data recorded were temperature $\left({ }^{\circ} \mathrm{C}\right), \mathrm{pH}$, electrical conductivity $\left(\mathrm{dS} \mathrm{m}{ }^{-1}\right)$, flow rate $\left(\mathrm{L} \mathrm{s}^{-1}\right)$ and total dissolved solids in $\mathrm{mg} \mathrm{L}^{-1}$. The sample was taken in 1 liter containers, from each sampling station in the desalination plant. To do this, simple samples (instantaneous) and composite samples (24 hours) were taken.

\section{Field parameters}

The variables evaluated from the plants were the percentage of germination $(\mathrm{G})$, percentage of flowering $(\mathrm{F})$, height of the plant (HP) and yield (Y). The percentage of germination was analyzed weekly from 15 days after sowing (das), where the numbers of plants germinated in rows $3 \mathrm{~m}$ long by $0.76 \mathrm{~m}$ wide were counted. To calculate the percentage, the number of total plants at $30 \mathrm{~cm}$ distance between the plants was taken as a reference. The percentage of flowering began to be measured at 59 das, taking as a reference the total number of germinated plants in each block. The yield was calculated in blocks of $5 \mathrm{~m}$ long by $1.52 \mathrm{~m}$ wide per treatment. The harvest was conducted manually when the castor beans were ripe to avoid losses. An experimental design of divided plots was used, where the large plots represent the four levels of salinity and the small plots represent the three hybrids used. The percentages of germination and flowering were measured in triplicate for each treatment, and the measurement of the yield and its components was carried out in five repetitions per treatment. All data were analyzed by a one-way ANOVA. When the main effect was significant, t-test was performed. Means separation among cultivar or salinity was conducted using Tukey's HSD multiple comparison. All statistical analyses were performed using Statgraphics plus (version 5.1).

\section{Results}

\section{Water quality-field parameters}

Table 1 shows the final averages of the quality parameters, considering temperature $\left({ }^{\circ} \mathrm{C}\right), \mathrm{pH}$, electrical conductivity $(\mathrm{mS} \mathrm{cm}$ $\left.{ }^{1}\right)$, total dissolved solids $\left(\mathrm{mg} \mathrm{L}^{-1}\right)$ and flow rate $\left(\mathrm{L} \mathrm{s}^{-1}\right)$, from the well supply water, rejected water (brine) and permeated water from the desalination process. Based on salinity in $\mathrm{mg} \mathrm{L}^{-1}$, the well water was classified as brackish water, the permeated water as drinking water, and the rejected water as saline. ${ }^{12}$ At the end of the project, the increase or decrease in the concentration of the well water was evaluated. The salinity of the well water increased by $14.08 \%$ due to its extraction and the lack of recharge of the aquifer due to lack of rain in the geographical area of the study. In contrast, the salinity of the permeated water decreased by $18.42 \%$. The salinity of the rejected water increased by $9.63 \%$ in the months of February to May.

Table I Averages of the quality parameters according to the type of water within the process

Feed: water supply to the desalination plant; Rejection: water rejection with high concentration of salinity;

Permeated: potable water; T: temperature; EC: electrical conductivity;TDS:Total Dissolved Solids; Q: flow rate.

\begin{tabular}{llllll}
\hline Water type & $\mathbf{T}\left({ }^{\circ} \mathbf{C}\right)$ & $\mathbf{p H}$ & $\mathbf{E C}\left(\mathbf{m S ~ c m} \mathbf{~}^{-1}\right)$ & TDS $\left(\mathbf{m g ~ L}^{-1}\right)$ & $\left.\mathbf{Q ~ ( L ~ s} \mathbf{~ s}^{-1}\right)$ \\
\hline Feed & 24.69 & 7.68 & 6.096 & $3,901.44 \pm 222.55$ & 0.315 \\
Rejection & 25.89 & 8.08 & 17.496 & $11,197.44 \pm 189.01$ & 0.063 \\
Permeated & 25.12 & 6.16 & 0.446 & $285.44 \pm 51.20$ & 0.252 \\
\hline
\end{tabular}

Table 2 Averages of the parameters of quality of the permeated water

T: temperature; EC: Electrical conductivity;TDS:Total Dissolved Solids.

\begin{tabular}{|c|c|c|c|c|}
\hline $\begin{array}{l}\text { Treatment } \\
\text { S a I i n i t y } \\
\left(\mathrm{dS} \mathrm{m}^{-1}\right)\end{array}$ & $\mathrm{T}\left({ }^{\circ} \mathrm{C}\right)$ & $\mathrm{pH}$ & $E C\left(\mathrm{mS} \mathrm{cm} \mathbf{c m}^{-1}\right)$ & TDS (mg L-1) \\
\hline 2.30 & 25.43 & 7.26 & 2.359 & $1,509.52 \pm 402.92$ \\
\hline 3.12 & 25.31 & 7.41 & 3.174 & $2,031.23 \pm 299.12$ \\
\hline 3.9 & 25.06 & 7.52 & 3.836 & $2,455.35 \pm 184.74$ \\
\hline 4.68 & 25.19 & 7.63 & 4.656 & $2,979.77 \pm 184.77$ \\
\hline
\end{tabular}

\section{Permeated water}

were prepared for each treatment $\left(2.30,3.12,3.9\right.$, and $\left.4.68 \mathrm{dS} \mathrm{m}^{-1}\right)$

The operation period of the desalination plant was from February 12 to June 18, 2016. During this period, 94 tanks of 5,000 L of water with a total volume per treatment of $470,000 \mathrm{~L}$. The total volume of mixture prepared for all treatments was $1,880,000 \mathrm{~L}$. 


\section{Permeated water quality}

Table 2 shows the final averages of the temperature $\left({ }^{\circ} \mathrm{C}\right), \mathrm{pH}$ electrical conductivity $\left(\mathrm{mS} \mathrm{cm}^{-1}\right)$ and total dissolved solids $\left(\mathrm{mg} \mathrm{L}^{-1}\right)$ of the product water stored in the 5,000 L tanks. The quality of the water obtained for irrigation is within the target ranges, given that the castor plant is considered a salinity-tolerant crop. ${ }^{13}$ According to the water quality guidelines for agricultural use, the National Water Commission indicates the following TDS ranges (in $\mathrm{mg} \mathrm{L}^{-1}$ ): 500 1,000 for sensitive crops, $1,000-2,000$ for special management and 2,000-5,000 for tolerant crops. ${ }^{4} \mathrm{The} \mathrm{pH}$ results are within the optimum range for crop irrigation, as established by García ${ }^{14}$ who reported that the normal water quality $\mathrm{pH}$ range for irrigation is from 6 to 8.5 .
The temperature of the permeated water was similar to the ambient temperature in all the treatments.

\section{Germination}

The increase in salinity concentration had a negative effect on germination at 15 das of all hybrids, which led to a reduction of 94.6 , 96.4 and $88 \%$ for Zoya 856 , Olga 864 and Galit K-93 compared to the treatments with lower concentrations of salts. At 28 das germination, the hybrids Zoya 856 and Olga 864 showed no significant response $(p>0.05)$ to the increase in salinity, while Galit K-93 showed a reduction of $27.5 \%$ (Table 3 ).

Table 3 Germination percentage of three castor plant hybrids (Zoya 586, Olga 864 and Galit K-93) on two dates, irrigated with four salinity concentrations: $2.3,3.12,3.9$ and $4.68 \mathrm{dS} \mathrm{m}^{-1}$

*The same lowercase letters inside the column and uppercase letters within the row indicate the values are not significantly different based on Tukey's mean comparison at $\mathrm{p}<0.05$.

\begin{tabular}{lllllllll}
\hline \multirow{2}{*}{ Hybrids } & I 5 das & \multicolumn{1}{c}{ 28 das } \\
\cline { 2 - 9 } & $\mathbf{2 . 3}$ & $\mathbf{3 . 1 2}$ & $\mathbf{3 . 9}$ & $\mathbf{4 . 6 8}$ & $\mathbf{2 . 3}$ & $\mathbf{3 . 1 2}$ & $\mathbf{3 . 9}$ & $\mathbf{4 . 6 8}$ \\
\hline Zoya 856 & $30.0 \mathrm{aA}$ & $11.6 \mathrm{bB}$ & $1.6 \mathrm{bB}$ & $1.6 \mathrm{aB}$ & $78.3 \mathrm{aA}$ & $68.6 \mathrm{aA}$ & $70.0 \mathrm{aA}$ & $65.0 \mathrm{aA}$ \\
Olga 864 & $45.0 \mathrm{aA}$ & $10.0 \mathrm{bB}$ & $1.6 \mathrm{bB}$ & $1.6 \mathrm{aB}$ & $73.3 \mathrm{aA}$ & $65.0 \mathrm{aA}$ & $65.0 \mathrm{aA}$ & $58.3 \mathrm{aA}$ \\
Galit K-93 & $55.0 \mathrm{aA}$ & $36.6 \mathrm{aAB}$ & $21.6 \mathrm{aBC}$ & $6.6 \mathrm{aC}$ & $85.0 \mathrm{aA}$ & $78.3 \mathrm{aAB}$ & $71.6 \mathrm{aAB}$ & $61.6 \mathrm{aB}$ \\
\hline
\end{tabular}

\section{Flowering}

Table 4 shows the effect of the increase in salinity concentration at 56 das, where the Galit K-93 hybrid showed the highest percentages of flowering in all treatments, Olga 864 did not show flowering above $3.12 \mathrm{dS} \mathrm{m}^{-1}$. At 79 das, there was no statistically significant difference between hybrids or between salinity concentrations, except for the Galit K-93 hybrid, which showed a $34.3 \%$ decrease in flowering percentage with increasing salinity up to $4.68 \mathrm{dSm}^{-1}$.

Table 4 Percentage of flowering castor plant hybrid (Zoya 586, Olga 864 and Galit K-93) at 56 das, irrigated with four concentrations of salinity *Identical lowercase letters inside the column and uppercase letters within the row indicate the values are not significantly different based on Tukey's test with $p<0.05$.

\begin{tabular}{lllll}
\hline Hybrids & $\mathbf{5 6}$ das & & & \\
& $\mathbf{2 . 3}$ & $\mathbf{3 . 1 2}$ & $\mathbf{3 . 9}$ & $\mathbf{4 . 6 8}$ \\
\hline Zoya 856 & $0.0 \mathrm{bA}$ & $0.0 \mathrm{bA}$ & $0.0 \mathrm{aA}$ & $0.0 \mathrm{bA}$ \\
Olga 864 & $8.1 \mathrm{bA}$ & $4.1 \mathrm{bA}$ & $0.0 \mathrm{aA}$ & $0.0 \mathrm{bA}$ \\
Galit K-93 & $51.0 \mathrm{aA}$ & $17.6 \mathrm{aB}$ & $14.9 \mathrm{aB}$ & $33.5 \mathrm{aAB}$ \\
\hline
\end{tabular}

\section{Plant height}

The height of the hybrids Zoya 856 and Olga 864 was not affected by increasing the salinity in the irrigation water. In contrast, the hybrid Galit K-93 showed a reduction in the final height of the plant of 7.2\%. The hybrids are classified as different sizes, with Galit K-93 being tall, Olga 864 medium and Zoya 856 short, with heights of 120.6, 92.5 and $69.9 \mathrm{~cm}$, respectively, in the control treatment.

\section{Yield}

The interaction between the salinity concentration and the hybrid used showed significant relationships with the yield (Figure 1). The hybrids Olga 864 and Zoya 856 showed a tendency to increase seed production as the concentration of salt in the irrigation water increased up to $4.68 \mathrm{dSm}^{-1}$, obtaining an increase of 26.77 and $33.23 \%$, respectively. The hybrid Olga 864 obtained the highest yields in all the treatments, above 1.5 ton $\mathrm{Ha}^{-1}$, achieving a maximum production of 2.28 ton $\mathrm{Ha}^{-1}$ in the treatment with the highest salinity.

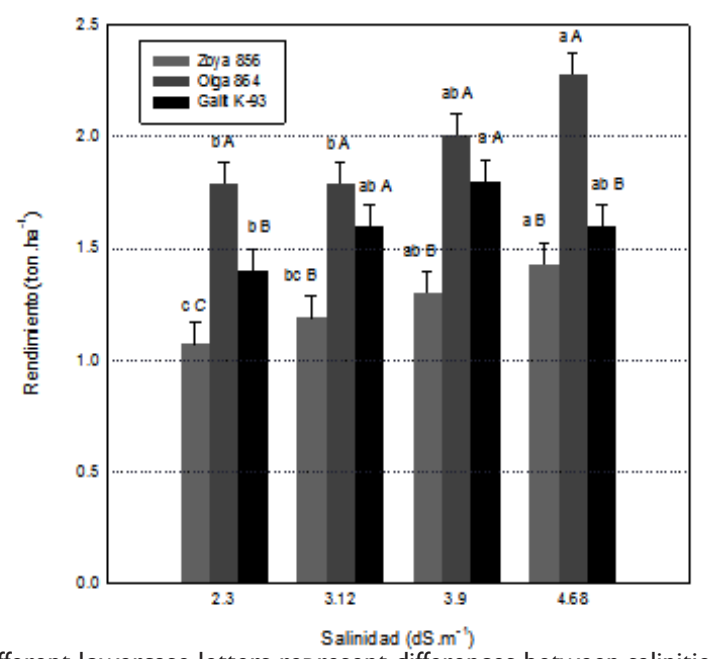

*Different lowercase letters represent differences between salinities and uppercase letters differences between hybrids based on Tukey's Mean Comparison with $\mathrm{p}<0.05$.

Figure I Yield of castor plant hybrids.

\section{Results and discussion}

Environmental factors such as soil moisture and salinity can influence physiological processes such as the germination of castor bean, for which the reported salinity limit is $7.1 \mathrm{dS} \mathrm{m} \mathrm{m}^{-1}(\mathrm{NaCl})$ resulting in percentages of germination less than $75 \%{ }^{15}$ In this study, with $4.68 \mathrm{dS} \mathrm{m}^{-1}$, germination percentages of $65,58.3$ and $61.6 \%$ were obtained for the hybrids Zoya 856, Olga 864 and Galit K-93, respectively. These results corroborate those of Fernandes et al. ${ }^{13}$ who indicated a significant decrease in the stages of development and growth of the studied seedlings. Sun et al. ${ }^{6}$ reported that increasing the level of salinity reduced the emergence of castor beans, and the effect varied among cultivars. The increase in the concentration of salts in the irrigation water delayed the germination of all hybrids for a period of 15 days. In most of the treatments, no significant difference 
was found between hybrids, except at 3.12 and $3.9 \mathrm{dS} \mathrm{m}^{-1}$, verifying the hypothesis proposed by Lima et al. (2014) that high levels of salinity in the irrigation of Ricinus communis $L$. negatively affect the growth of the plant leaves. The flowering of the castor plant crop appeared approximately 50 das. Barrios et al. ${ }^{16}$ found ranges of days to flowering from 40 to 72 das in the state of Morelos, Mexico, while in Montecillo, Mexico, they reported fluctuation of this parameter between 99 and 149 das. ${ }^{17}$ The differences may be due to the location of the study and the climatic characteristics of the areas. A decrease in the height of the plant has been reported in previous studies with irrigation water salinity of $5 \mathrm{dS} \mathrm{m}^{-1},{ }^{13}$ along with decreases in the length of the stem, leaves, and weight. This, together with the cultivation of castor plant in saline soils, affects the growth and protein content of the fruit. ${ }^{18,19}$ The yield of castor plants is the variable that determines the productivity of the hybrid and therefore the viability of its use for commercial purposes, and this parameter is often used to evaluate the tolerance of the crop to salinity. It is suggested that there is a great diversity regarding tolerance to salts among the different varieties of Ricinus communis L. ${ }^{6,13}$ In this study, the Olga 864 hybrid tolerated salinity up to $4.68 \mathrm{dS} \mathrm{m}^{-1}$ and increased its production above 2 ton $\mathrm{ha}^{-1}$. These results corroborate those reported by Severino et al. ${ }^{11}$ who found that different varieties of castor plant presented high levels of yield in high salinities. ${ }^{20-22}$

\section{Conclusion}

The three castor plant hybrids evaluated tolerated the four salinity concentrations, reaching acceptable yields up to 1,978 ton $\mathrm{ha}^{-1}$. The highest yield was obtained with the Olga 864 hybrid at a concentration of $4.68 \mathrm{dS} \mathrm{m}^{-1}$ in the irrigation water. The salinity of the irrigation water affected the germination of the castor plant hybrids, delaying the stage by approximately 15 days, with equal germination percentages of all the hybrids. The yield of the castor plant increased as the salinity of the irrigation water increased from 2.3 to $4.68 \mathrm{dS} \mathrm{m}^{-1}$, obtaining the highest yield value at the most saline level, in contrast to the hypothesis proposed in this investigation. It is favorable to use modern systems of water desalination by reverse osmosis for the irrigation of crops sensitive to salinity.

\section{Acknowledgements}

None.

\section{Conflict of interest}

The authors declare that there is no conflict of interest.

\section{References}

1. González IC, Ureta KE. Shortage of water: in search of regulatory solutions. Economy Informa. 2012;374: 53-74.

2. Ojeda A, Alvarez C, Ramos MA, et al. Determinants of domestic water in Hermosillo, Sonora, Mexico. Journal of Cleaner Production. 2017;142:1901-1910.

3. Castellanos AE, Martínez MJ, Llano WL, et al. Successional trends in Sonoran Deserted agricultural fields in northern Mexico. Journal of Arid Environments. 2005;60(3):437-455.

4. CONAGUA. Federal Law of Rights. Provisions applicable in matters of National Waters. Coyoacán, Mexico City, Mexico. 2016.

5. Dévora-Isiordia GE, López M, Fimbres G, et al. Desalination by reverse osmosis and its use in agriculture in the Yaqui Valley, Sonora, Mexico. Technology and Water Sciences. 2016;7:155-169.

6. Sun Y, Niu G, Osuna P, et al. Seedling emergence, growth, and leaf mineral nutrition of Ricinus communis L. cultivars irrigated with saline solution. Industrial Crops and Products. 2013;49:75-80.

7. Lechuga J, Rodríguez M, Lloveras J. Analysis of the processes for desalination of seawater applying competitive and technological intelligence. Engineering. 2007;11:5-14.

8. Dévora-Isiordia GE, González R, Ruiz S. Evaluation of desalination processes and their development in Mexico. Technology and water science. 2013;4(3):27-46.

9. Babita M, Maheswari M, Rao L, et al. Osmotic adjustment, drought tolerance and yield in castor (Ricinus communis L.) hybrids. Environmental and Experimental Botany. 2010;69(3):243-249.

10. Rico H, Tapia L, Lieutenant R, et al. Guide to grow Higuerilla (Ricinus communis L.) in Michoacan, Mexico. National Institute of Forestry, Agriculture and Livestock Research. 2011;1-43.

11. Severino LS, Auld DL, Baldanzi M, et al. A review on the challenges for increased production of beaver. Agronomy Journal. 2012;104:853-880.

12. Dévora-Isiordia GE, Gonzalez R, Saldivar J. Design of desalination processes of brackish groundwater through chemical simulation of reversible electrodialysis, for human consumption purposes. Revista Latinoamericana de Recursos Naturales. 2009;5:31-41.

13. Fernandes CR, Nascimento E, da Mata R, et al. Physiological adjustment to salt stress in R. Communis seedlings is associated with a probable mechanism of osmotic adjustment and a reduction in water lost by transpiration. Industrial Crops and Products. 2014;54:233-239.

14. Garcia A. Modern criteria for the evaluation of water quality for irrigation. Agronomic Information of Hispano-America Journal. 2012;6:27-36.

15. Severino LS, Auld DL. A framework for the study of the growth and development of castor plant. Industrial Crops and Products. 2013;46:25-38.

16. Barrios EJ, Zamarripa A, Canul J, et al. Evaluation of elite materials of Higuerilla (Ricinus communis L.) in Morelos. Agricultural Science and Technology Mexico. 2013;1:27-32.

17. Solís JL, Muñoz A, Escalante JA, et al. Growth of varieties and yield components of castor bean (Ricinus communis L.) in Montecillo, State of Mexico. Revista Mexicana de Ciencias Agrícolas. 2016;7(2):311-323.

18. Bauddh K, Singh R. Growth, tolerance efficiency and phytoremediation potential of Ricinus Communis (L.) and Brassica Juncea (L.) in salinity and drought affected cadmium contaminated soil. Ecotoxicology and Environmental Safety. 2012;85:13-22.

19. Severino LS, Cordoba GOJ, Zanotto MD, et al. The influence of the caruncle on the germination of castor seed under high salinity or low soil water content. Seed Science Technology. 2012;40:139-143.

20. González LM, Zamora A, Céspedes N. Salinity tolerance in cultivars of Vigna unguiculata (L.) Walp during the initial stages of plant growth. Alimentaria. 2000;314:105-108.

21. Niu G, Sun Y, Osuna P. Irrigating bioenergy crops with alternative waters. Memory of XXV international week of agronomy FAZ-UJED. 2013;63-67.

22. Rodriguez JC, Grageda J, Watts CJ, et al. Water use by perennial crops in the lower Sonora watershed. Journal of Arid Environments. 2010;74(5):603-610. 